\title{
Evaluation of Biocontrol Agents in Management of Wilt Disease of Gladiolus Caused by Fusarium oxysporum F. Sp. Gladioli
}

\author{
Venkatesh Javali ${ }^{*}$, S. Sriram and Neethu K. Chandran \\ Division of Plant Pathology, IIHR, Bengaluru, India \\ *Corresponding author
}

\begin{tabular}{|l|}
\hline Ke y w o r d s \\
Trichoderma, \\
$\begin{array}{l}\text { Gladiolus, } \\
\text { Fusarium wilt, Dual } \\
\text { culture, Volatile } \\
\text { compounds }\end{array}$ \\
\hline Article Info \\
\hline $\begin{array}{l}\text { Accepted: } \\
\text { 07 May } 2019 \\
\text { Available Online: } \\
\text { 10 June } 2019\end{array}$ \\
\hline
\end{tabular}

\section{Introduction}

Gladiolus (Gladiolus hybridus Hort.) belongs to the family Iridaceae. It is one of the important ornamental bulbous flower crops. It is mainly grown for its beautiful flowers. Owing to their different sizes, shades and excellent vase life, gladiolus hybrids are one among the preferred cut flowers (Bose et al., 2003; Riaz et al., 2008).
Fusarium oxysporum f. sp. gladioli cause wilt in gladiolus. Fusarium wilt is a major constraint to flower industry with respect to good quality and yield. Use of fungicides for the management of Fusarium wilt has been found to be inconsistent. Application of biocontrol agents constitutes an effective option for the management of Fusarium wilt. The present study was carried out to analyze the efficacy of biocontrol agents against Fusarium wilt. Twenty eight Trichoderma isolates and one fluorescent pseudomonad isolate were tested in vitro for their efficacy against Fusarium wilt pathogen of gladiolus. Isolates of $T$. harzianum (IIHR09, GJ16B, TN2A, HAR4B) and fluorescent pseudomonad (IIHRFP1) were found effective and further evaluated in vivo. All Trichoderma isolates were found effective in controlling Fusarium wilt of gladiolus in pot experiment while, 77.77 and 44.44 per cent of wilt incidence was observed in case of control and fluorescent pseudomonad isolate. Field trial for the management of Fusarium wilt of gladiolus using carbendazim tolerant Trichoderma isolate GJ16B was found effective that reduced wilt incidence from 18 to 4 per cent. The biocontrol mechanism studies revealed that selected Trichoderma isolates were possessed good competitive saprophytic ability. The isolate HAR4B was found to be the best in production of volatile compounds, while isolate GJ16B was the best in non-volatile compounds production. Besides GJ16B possessed strong mycoparasitic ability against Fusarium oxysporum f. sp. gladioli. 
soil from one region to another and at times from one country to another. It becomes necessary to manage the disease both in field and storage conditions. Management strategies for Fusarium wilt were sanitation measures, using healthy corms, soil fumigation and using chemicals. Due to high cost of chemicals, loss of soil microflora and environmental pollution by using chemicals for management of disease, the use of other cultural practices and introduction of biological control agents may be an alternative for managing the disease (Chandel and Deepika, 2010). In the present work the evaluation for efficacy of Trichoderma isolates in management of Fusarium wilt of gladiolus was studied.

\section{Materials and Methods}

\section{Isolation of the pathogen}

The wilted gladiolus plants along with rotten corms were collected from Solan, Himachal Pradesh. Infected rotted corms of gladiolus were used for the isolation of Fusarium pathogen. Tissue isolation technique was followed for the isolation of the pathogen by placing infected bits on Petri plates containing potato dextrose agar media and incubated at ambient temperature $\left(27 \pm 2^{0} \mathrm{C}\right)$ and observed periodically for the growth of pure colonies. The colonies were developed from the bits transferred to PDA plates to get pure colonies and incubated at $27 \pm 1^{\circ} \mathrm{C}$ for 7 days. The Fusarium plates were used to study the cultural characters in the laboratory based on the morphological and cultural characters by Booth (1971).

\section{Isolation of antagonist from the rhizosphere region}

The Trichoderma was isolated from soil by using Trichoderma selective medium (TSM) developed by Elad and Chet (1983). Standard serial dilution technique was adopted for the isolation of antagonist from the rhizosphere region soil. Finally the dilutions of $10^{-5}$ and $10^{-6}$ were plated and plates were incubated at room temperature $\left(28 \pm 2{ }^{0} \mathrm{C}\right)$ for five days and observed daily for appearance of Trichoderma colonies. The pure culture obtained was maintained in silica gel in refrigerator. Twenty one isolates of Trichoderma were obtained from the National Bureau of Agricultural important Insects (NBAII), Bengaluru to test their efficacy against the $F$. oxysporum f. sp. gladioli (FOG).

Screening of the fungal antagonists against f. oxysporum f. sp. gladioli in vitro

Twenty eight Trichoderma isolates and one fluorescent pseudomonad isolate were screened against $F$. oxysporum f. sp. gladioli by following dual culture method (Dennis and Webster, 1971a). The radial growth of the pathogen was measured at fifth and seventh day and per cent inhibition over control was worked out according to the equation given by Vincent (1927).

In vivo evaluation of bioagents against fusarium oxysporum f. sp. gladioli

The pots were filled with sterilized soil. Talc formulations of bioagents were delivered as seedling dip at the rate of $10 \mathrm{~g}$ per litre with spore count $4.1 \times 10^{5} \mathrm{cfu} / \mathrm{g}(\mathrm{GJ} 16 \mathrm{~B}), 4.8 \mathrm{x}$ $10^{5} \mathrm{cfu} / \mathrm{g}$ (IIHR 9), $4.7 \times 10^{5} \mathrm{cfu} / \mathrm{g}$ (HAR4B), $4.5 \times 10^{5} \mathrm{cfu} / \mathrm{g}$ (IIHR FP1) and $4.9 \times 10^{5} \mathrm{cfu} / \mathrm{g}$ (TN2A) of the formulation used.

The corms were planted in respective assigned pots. Each pot was planted with three corms of gladiolus. After 15 days of planting the mass multiplied pathogen was inoculated at rate of $2.6 \times 10^{6}$ spores $/ \mathrm{ml}$ to root zone and properly mixed. Regular observations were recorded. 
Trial on the management of gladiolus wilt with carbendazim tolerant trichoderma harzianum isolates

A preliminary trial with carbendazim tolerant Trichoderma harzianum isolate (NBAIR, GJ16B) on the management of gladiolus wilt was carried out. The isolate was developed at NBAIR and the same was tested as soil application and corm treatment. The experiment was carried under natural field conditions. Three replications were maintained for each treatment. Talc formulation of the bioagents was used for treating the corms and soil application. Germination percentage and per cent wilt incidence was recorded.

\section{Biocontrol mechanism studies}

\section{Competition}

The dual culture method described earlier was followed to study the competition between selected Trichoderma isolates (GJ16B, IIHR 9, HAR 4B and TN2A) against FOG and the data was recorded at fifth and seventh day and the per cent inhibition was calculated and expressed in percentage.

\section{Antibiosis production of volatile inhibitory compounds by trichoderma against fusarium oxysporum f. sp. gladioli}

The test was carried out by slightly modifying the sealed Petri plate technique described by Dennis and Webster (1971b). For this experiment two Petri dish bases $(90 \mathrm{~mm})$ containing $20 \mathrm{ml}$ of solidified two per cent malt agar medium were sealed together by an adhesive tape and the candidate fungus (antagonistic fungus) was grown in the bottom plate corresponding upper plate was inoculated with the pathogen and incubated at $25 \pm 2^{\circ} \mathrm{C}$, allowing the medium on the upper plate to absorb any volatile compounds produced by the candidate fungus and radial growth of pathogen was recorded after third, fifth and seventh day compared with the growth in control plates. Based on the result, percentage inhibition of pathogen was calculated.

\section{Non-volatile compound estimation}

The production of non-volatile substances by Trichoderma isolates against FOG isolate was studied using the method described by Dennis and Webster (1971b). Trichoderma isolates were inoculated in double strength $100 \mathrm{ml}$ sterilized potato dextrose broth (PDB) in 250 $\mathrm{ml}$ conical flasks and incubated at $26 \pm 2{ }^{\circ} \mathrm{C}$ for ten days. The control flasks with single strength of potato dextrose broth were not inoculated with any of the culture. The Trichoderma culture was filtered through Whatmann filter paper for removing mycelial mat after ten days and sterilized by passing through $0.2 \mu \mathrm{m}$ pore biological membrane filter.

Later the filtered potato dextrose broth was inoculated with the FOG isolate and control flask were inoculated with the pathogen and incubated at $26 \pm 2{ }^{0} \mathrm{C}$ for seven days. The mycelium mats of all the flasks were collected separately and the dry mycelial weight of all were taken to know the per cent reduction of growth of the pathogen over control.

\section{Mycoparasitism of Trichoderma on $F$. oxysporum f. sp. gladioli}

Dual culture method was followed by placing the selected isolates of Trichoderma on one end of the petri plate and the other end of the plate was inoculated with Fusarium oxysporum f. sp. gladioli. Mycelial samples were carefully taken from the interaction region of both the fungi, were fixed on the slides very carefully without disturbing the mycelial mat and observed under microscope 
for the presence of coiling structures and they were photographed (Watanabe, 1984).

\section{Results and Discussion}

Total of nine isolates of Trichoderma spp. and one fluorescent pseudomonad were isolated from the rhizosphere region of soil. From dual culture method it was found that the Trichoderma harzianum isolates IIHR9, TN2A, GJ16B and HAR4B, IIHRFP1 fluorescent pseudomonad isolate were found to be best, they were further evaluated in vivo against FOG.

In vivo evaluation of bioagents against $F$. oxysporum f. sp. gladioli

The experimental results of evaluation of bioagents against $F$. oxysporum $\mathrm{f}$. sp. gladioli revealed there was significant effect of bioagents in controlling of Fusarium wilt. No wilting symptoms was observed in any plants treated with Trichoderma isolates while wilt incidence was 44.44 per cent in fluorescent pseudomonad treated plants with pathogen inoculation and 77.77 per cent in control inoculated only with pathogen. Similarly, Fusarium crown rot of tomatoes was reduced by 80 per cent when $T$. harzianum was applied as seed coating which also resulted in enhanced yield (Sivan et al., 1987). T. viride (T-1) strain was used by Marois and Locke (1985) for controlling of the Fusarium wilt of chrysanthemum. The result indicated 50 per cent reduction in wilt disease caused by $F$. oxysporum f. sp. chrysanthemi.

Maximum plant height was observed in Trichoderma isolate GJ16B $(109.91 \mathrm{~cm})$ which was significantly superior over all treatments in experiment of without pathogen inoculation. Maximum plant height in experiments inoculated with pathogens was observed in isolate GJ16B $(109.20 \mathrm{~cm})$ which was statistically on par with isolate TN2A
(108.44 cm). The least plant height was observed in isolate IIHR FP $1(105.11 \mathrm{~cm})$. The increased growth response induced by Trichoderma spp. is not fully understood. However, several possible mechanisms have been suggested to explain the phenomenon increase of plant growth. These factors may include (i) control of deleterious root microorganisms those were not causing obvious diseases (ii) direct production of growth stimulating factors, (iii) increased nutrient uptake through enhanced root growth or promoted availability of necessary nutrients, (iv) reduction in the concentrations of substances in soil that are inhibitory to plant growth (Sivan and Harman, 1991).

Spike length was highest in isolate GJ16B $(107 \mathrm{~cm})$ which was statistically on par with control plants $(106.5 \mathrm{~cm})$ without inoculation of pathogen and carbendazim treated plants $(106.4 \mathrm{~cm})$. The lowest stalk length was observed in isolate IIHR FP1 $(101.25 \mathrm{~cm})$. The maximum stalk length was observed in treatment GJ16B with pathogen inoculation $(106.23 \mathrm{~cm})$ and the least stalk length was observed in control plants $(100.15 \mathrm{~cm})$ with only pathogen. There was no effect of bioagents on floral characters like number of florets per spike, floret diameter and floret length and were found to be non-significant in both pathogen inoculated treatment and without any inoculation of pathogen. The details of parameters of different treatments were presented in table 1 and 2 .

Trial on the management of gladiolus wilt with carbendazim tolerant Trichoderma harzianum isolate

The results of trial on management of FOG revealed that there was significant difference observed between the treatments for wilt incidence and data is given in table 3 . The maximum germination percentage was observed in $T$. harzianum isolate GJ16B 
(96\%), which was statistically on par with treatments of carbendazim + Trichoderma $(94 \%)$, carbendazim $(92 \%)$ and hot water treatment (92\%). The least germination percentage was observed in treatment control (84\%) which was statistically on par with treatment of hot water + carbendazim $(85 \%)$.

Wilt incidence due to Fusarium was ranging from 4 to 18 per cent under field condition in the preliminary trial and wilt incidence varied significantly among the treatments. The highest wilt incidence was observed in control (18\%), and lowest wilt incidence was observed in treatment of isolate GJ16B (4.1\%) which was statistically on par with treatment of hot water + Trichoderma $(4.3 \%)$ and carbendazim + Trichoderma $(5.7 \%)$.

\section{Biocontrol mechanism studies}

\section{Computation}

Four isolates of $T$. harzianum, were tested for their antifungal activity against $F$. oxysporum f. sp. gladioli. There was significant variation among the isolates was observed. The highest per cent inhibition of radial mycelial growth was observed in isolate GJ16B (65.83\%) which was statistically on par with isolate TN2A (65.24\%), followed by isolate IIHR 9 (58.63\%) and HAR4B (55.04\%). The per cent inhibition ranged 55.04 to 68.83 per cent and data is presented table 4 .

The results were in agreement with that of Mishra et al., 2004 were they studied, T. virens isolates against Fusarium oxysporum $\mathrm{f}$. sp. gladioli were analysed by dual plate method, the growth of Trichoderma was significantly faster than FOG and it was capable of growing over FOG colonies by its competitive nature. Isolate GJ16B showed highest inhibitory effect on FOG by inhibiting the radial mycelial growth. The rapid growing ability of Trichoderma may probably provide an advantage in competing for nutrients and space utilization. The role of competition for nutrient and space in suppressing the populations of Fusarium species has been explained by other researchers (Cugudda and Garibaldi, 1987; Widden and Scattolin, 1988).

Efficacy of volatile compounds produced by Trichoderma spp. against $F$. oxysporum f. sp. gladioli

Volatile compounds released from $T$. virens were studied by Mishra et al., (2004), where significant inhibition of colony growth of the $F$. oxysporum f. sp. gladioli on PDA was observed upto a tune of 53 per cent. A comparison between the inhibitory effects of volatile metabolites in the present study revealed that the maximum inhibition of $F$. oxysporum f. sp. gladioli by volatile compound production was observed by isolate GJ16B (40.21\%) and was statistically on par with isolate HAR4B (37.50\%). The minimum inhibition of 23.91 per cent was observed with isolate IIHR 9 on third day. On fifth day the isolate GJ16B was reduced the pathogen growth by 36.61 per cent and was statistically superior over other isolates. Isolate $\mathrm{TN} 2 \mathrm{~A}$ was the least effective with 21.28 per cent inhibition. On seventh day results showed that the isolate HAR4B was found most effective with 55.20 per cent reduction in the mycelial growth and was statistically on par with isolate GJ16B (52.80\%). Isolate TN2A showed 48.00 percent reduction which was statistically on par with IIHR 9 isolate $(47.20 \%)$ and the data were presented in table 5.

The results indicated that the volatile metabolites seemed to be more effective in the antagonistic mechanism. Such findings were also reported by El-Katatny et al., (2001) who explained the biocontrol efficacy of $T$. harzianum (T24) against Sclerotium rolfsii due to over production of volatile 
metabolites. Inhibitory effects through volatile compounds were evident with $T$. harzianum, T. viride and T. virens against soil borne fungal pathogens identified by Mukherjee and Tripathi (2000).

\section{Effect of non-volatile metabolites produced by selected trichoderma isolates against $F$. oxysporum f. sp. gladioli}

The selected isolates of Trichoderma were evaluated for the production of non-volatile compound production and its effect on the FOG growth was done has described earlier. The dry mycelial weight was taken and compared with the control. The data obtained on weight of dry mycelial growth of FOG was presented in the table 6 .

All the selected isolates produced non-volatile compounds and inhibited the growth of gladiolus Fusarium. The maximum dry mycelial weight was observed in control. The maximum dry mycelial weight of $F$. oxysporum f. sp. gladioli (1.096 g) was observed in control and minimum mycelial weight was observed in isolate GJ16B $(0.4790 \mathrm{~g})$ with 56.29 per cent reduction of mycelial weight over control and was statistically on par with isolates IIHR 9 $(0.5744 \mathrm{~g})$ and TN2A $(0.6870 \mathrm{~g})$. Dennis and Webster (1971b) showed the effect of diffusible antibiotic produced by Trichoderma spp. against a wide range of fungal pathogens. The antibiotics produced by different Trichoderma spp. varied from isolate to isolate, which were toxic to pathogen and inhibited the growth of pathogen. Kamala and Indra (2011) showed the inhibitory effect of non-volatile compounds produced by indigenous Trichoderma isolates, and observed that out of 20 isolates used for study only five isolates were able to produce nonvolatile compounds and significantly inhibited the growth of pathogen.

Table.1 Effect of talc formulated Trichoderma isolates and fluorescent pseudomonad isolate on plant growth parameters in gladiolus under pot culture conditions

\begin{tabular}{|c|c|c|c|c|c|c|c|}
\hline Treatment & $\begin{array}{l}\text { Plant height } \\
\text { at harvest } \\
(\mathrm{cm})\end{array}$ & $\begin{array}{l}\text { Days to bud } \\
\text { emergence }\end{array}$ & $\begin{array}{l}\text { Days taken } \\
\text { for first floret } \\
\text { opening }\end{array}$ & $\begin{array}{c}\text { Spike } \\
\text { length }(\mathrm{cm})\end{array}$ & $\begin{array}{c}\text { No. of } \\
\text { florets } \\
\text { per spike }\end{array}$ & $\begin{array}{c}\text { Floret } \\
\text { diameter } \\
(\mathrm{cm})\end{array}$ & $\begin{array}{c}\text { Floret } \\
\text { length } \\
(\mathrm{cm})\end{array}$ \\
\hline $\begin{array}{l}\text { Trichoderma harzianum } \\
\text { isolate GJ16B }\end{array}$ & $109.91^{\mathrm{a}}$ & $71.13^{\mathrm{d}}$ & $83.00^{\mathrm{de}}$ & $107.00^{\mathrm{a}}$ & 18.29 & 10.61 & 10.36 \\
\hline $\begin{array}{l}\text { Trichoderma harzianum } \\
\text { isolate IIHR } 9\end{array}$ & $106.81^{d}$ & $74.85^{\mathrm{a}}$ & $84.77^{b}$ & $104.28^{b}$ & 18.08 & 10.50 & 10.30 \\
\hline $\begin{array}{l}\text { Trichoderma harzianum } \\
\text { isolate HAR4B }\end{array}$ & $107.63^{c}$ & $74.50^{\mathrm{ab}}$ & $84.35^{\mathrm{bc}}$ & $104.57^{b}$ & 18.16 & 10.53 & 10.33 \\
\hline $\begin{array}{l}\text { fluorescent pseudomonad } \\
\text { isolate IIHR FP1 }\end{array}$ & $107.00^{d}$ & $74.00^{b}$ & $86.50^{\mathrm{a}}$ & $101.25^{c}$ & 18.04 & 10.34 & 10.35 \\
\hline $\begin{array}{l}\text { Trichoderma harzianum } \\
\text { isolate TN2A }\end{array}$ & $108.75^{b}$ & $73.00^{c}$ & $84.15^{b c}$ & $106.51^{\mathrm{a}}$ & 18.10 & 10.67 & 10.32 \\
\hline Carbendazim @ 0.1\% & $108.41^{b}$ & $72.43^{c}$ & $83.74^{\text {cd }}$ & $106.40^{\mathrm{a}}$ & 18.00 & 10.44 & 10.32 \\
\hline $\begin{array}{l}\text { Thiram + Carboxin @ } \\
0.1 \%\end{array}$ & $108.45^{b}$ & $72.86^{\mathrm{c}}$ & $84.82^{b}$ & $106.58^{\mathrm{a}}$ & 18.05 & 10.50 & 10.35 \\
\hline Control & $108.33^{b}$ & $71.00^{\mathrm{d}}$ & $82.67^{\mathrm{e}}$ & $106.50^{\mathrm{a}}$ & 18.58 & 10.33 & 10.39 \\
\hline SEm \pm & 0.20 & 0.23 & 0.26 & 0.23 & 0.56 & 0.39 & 0.39 \\
\hline CD@ $9 \%$ & 0.59 & 0.66 & 0.76 & 0.68 & NS & NS & NS \\
\hline
\end{tabular}


Table.2 Effect of talc formulated Trichoderma isolates and fluorescent pseudomonad isolate on plant growth parameters in gladiolus under pot culture conditions in presence of virulent pathogen

\begin{tabular}{|c|c|c|c|c|c|c|c|c|}
\hline Treatment & $\begin{array}{l}\text { Plant height } \\
\text { at harvest } \\
(\mathrm{cm})\end{array}$ & $\begin{array}{l}\text { Days to bud } \\
\text { emergence }\end{array}$ & $\begin{array}{c}\text { Days taken } \\
\text { for first floret } \\
\text { opening }\end{array}$ & $\begin{array}{l}\text { Spike } \\
\text { length } \\
(\mathrm{cm})\end{array}$ & $\begin{array}{c}\text { No. of } \\
\text { florets } \\
\text { per spike }\end{array}$ & $\begin{array}{c}\text { Floret } \\
\text { diameter } \\
(\mathbf{c m})\end{array}$ & $\begin{array}{l}\text { Floret } \\
\text { length } \\
(\mathrm{cm})\end{array}$ & $\begin{array}{l}\text { \% Wilt } \\
\text { incidence }\end{array}$ \\
\hline $\begin{array}{l}\text { Trichoderma harzianum isolate GJ16B + } \\
\text { FOG SOLAN }\end{array}$ & $109.20^{\mathrm{a}}$ & $70.20^{b}$ & $82.20^{\mathrm{d}}$ & $106.00^{\mathrm{ab}}$ & 18.27 & 10.56 & 10.27 & $0(0.28)$ \\
\hline $\begin{array}{l}\text { Trichoderma harzianum isolate IIHR } 9+ \\
\text { FOG SOLAN }\end{array}$ & $106.13^{\mathrm{cd}}$ & $71.80^{\mathrm{a}}$ & $83.00^{\mathrm{b}}$ & $104.18^{c}$ & 18.04 & 10.30 & 10.18 & $0(0.28)$ \\
\hline $\begin{array}{l}\text { Trichoderma harzianum isolate HAR4B + } \\
\text { FOG SOLAN }\end{array}$ & $106.71 \mathrm{bcd}$ & $71.80^{\mathrm{a}}$ & $82.30^{\mathrm{cd}}$ & $103.74^{c}$ & 18.09 & 10.31 & 10.22 & $0(0.28)$ \\
\hline $\begin{array}{l}\text { Fluorescent pseudomonad isolate IIHR } \\
\text { FP1 + FOG SOLAN }\end{array}$ & $105.11^{d}$ & $71.00^{\mathrm{ab}}$ & $82.88^{\mathrm{bc}}$ & $100.15^{\mathrm{d}}$ & 18.02 & 10.40 & 10.26 & $\begin{array}{c}44.44 \\
(41.80)\end{array}$ \\
\hline $\begin{array}{l}\text { Trichoderma harzianum isolate TN2A + } \\
\text { FOG SOLAN }\end{array}$ & $108.44^{\mathrm{a}}$ & $71.80^{\mathrm{a}}$ & $84.00^{\mathrm{a}}$ & $105.58^{\mathrm{ab}}$ & 18.10 & 10.60 & 10.20 & $0(0.28)$ \\
\hline Carbendazim @0.1\% + FOG SOLAN & $107.99^{\mathrm{ab}}$ & $71.00^{\mathrm{ab}}$ & $83.40^{\mathrm{ab}}$ & $105.60^{\mathrm{ab}}$ & 18.00 & 10.56 & 10.20 & $0(0.28)$ \\
\hline $\begin{array}{l}\text { Thiram + Carboxin @ } 0.1 \%+\text { FOG } \\
\text { SOLAN }\end{array}$ & $107.71^{\mathrm{abc}}$ & $71.00^{\mathrm{ab}}$ & $83.20^{\mathrm{b}}$ & $105.48^{b}$ & 18.03 & 10.50 & 10.25 & $0(0.28)$ \\
\hline FOG SOLAN & $108.11^{\mathrm{ab}}$ & $68.6^{c}$ & $80.40^{\mathrm{e}}$ & $106.23^{\mathrm{a}}$ & 18.44 & 10.39 & 10.32 & $\begin{array}{c}77.77 \\
(61.87)\end{array}$ \\
\hline SEm \pm & 0.59 & 0.39 & 0.23 & 0.25 & 0.55 & 0.39 & 0.47 & 0.11 \\
\hline CD@ $9 \%$ & 1.70 & 1.12 & 0.65 & 0.72 & NS & NS & NS & 0.35 \\
\hline
\end{tabular}


Table.3 Field trial data of carbendazim tolerant Trichoderma harzianum isolate GJ16B

\begin{tabular}{|l|c|c|}
\hline \multicolumn{1}{|c|}{ Treatment } & \% germination & \% wilt incidence \\
\hline Control & $84.00^{\mathrm{a}}$ & $18.00^{\mathrm{c}}(25.09)$ \\
\hline Hot water treatment & $92.00^{\mathrm{b}}$ & $9.60^{\mathrm{b}}(18.04)$ \\
\hline Carbendazim & $92.00^{\mathrm{b}}$ & $7.60^{\mathrm{b}}(15.99)$ \\
\hline Trichoderma harzianum & $96.00^{\mathrm{b}}$ & $4.10^{\mathrm{a}}(11.68)$ \\
\hline Hot water + Trichoderma & $88.00^{\mathrm{ab}}$ & $4.30^{\mathrm{a}}(11.96)$ \\
\hline Carbendazim + Trichoderma & $94.00^{\mathrm{b}}$ & $5.70^{\mathrm{ab}}(13.80)$ \\
\hline Hotwater + carbendazim & $85.00^{\mathrm{a}}$ & $8.60^{\mathrm{b}}(17.05)$ \\
\hline SEm \pm & $\mathbf{1 . 7 2}$ & $\mathbf{1 . 9 9}$ \\
\hline CD @ 5\% & $\mathbf{5 . 2 0}$ & $\mathbf{6 . 0 1}$ \\
\hline
\end{tabular}

Values following same letter don't differ significantly at $(\mathrm{P}=0.05)$ by DMRT

Table.4 Growth of F. oxysporum f. sp. gladioli and bioagents in dual culture

\begin{tabular}{|c|c|c|c|c|c|c|}
\hline \multirow{2}{*}{$\begin{array}{l}\text { Trichoderma } \\
\text { isolates }\end{array}$} & \multicolumn{3}{|c|}{$5^{\text {th }}$ Day } & \multicolumn{3}{|c|}{$7^{\text {th }}$ Day } \\
\hline & $\begin{array}{l}\text { Trichoderma } \\
\text { (cm) }\end{array}$ & $\begin{array}{l}\text { FOG } \\
(\mathrm{cm})\end{array}$ & $\begin{array}{l}\text { Per cent } \\
\text { reduction in } \\
\text { FOG over } \\
\text { control }\end{array}$ & $\begin{array}{l}\text { Trichoderma } \\
\text { (cm) }\end{array}$ & FOG (cm) & $\begin{array}{l}\text { Per cent reduction in } \\
\text { FOG over control }\end{array}$ \\
\hline GJ 16 B & $7.15^{\mathrm{a}}$ & $1.44^{\mathrm{c}}$ & 59.10 & $8.25^{\mathrm{a}}$ & $1.90^{\mathrm{d}}$ & 65.83 \\
\hline TN 2 A & $6.85^{\mathrm{b}}$ & $1.50^{\mathrm{c}}$ & 57.39 & $8.00^{\mathrm{b}}$ & $2.10^{\mathrm{cd}}$ & 62.24 \\
\hline HAR 4 B & $6.70^{\mathrm{b}}$ & $1.98^{\mathrm{b}}$ & 43.75 & $7.80^{\mathrm{c}}$ & $2.50^{\mathrm{b}}$ & 55.04 \\
\hline IIHR9 & $6.24^{\mathrm{c}}$ & $2.20^{\mathrm{b}}$ & 37.50 & $7.50^{\mathrm{d}}$ & $2.30^{\mathrm{bc}}$ & 58.63 \\
\hline Control & - & $3.52^{\mathrm{a}}$ & - & - & $5.56^{\mathrm{a}}$ & - \\
\hline $\mathrm{SEm} \pm$ & 0.09 & 0.08 & & 0.05 & 0.08 & \\
\hline CD at $1 \%$ & 0.38 & 0.37 & & 0.27 & 0.36 & \\
\hline
\end{tabular}

Values following same letter don't differ significantly at $(\mathrm{P}=0.01)$

Table.5 Influence of volatile compounds released by selected Trichoderma isolates in vitro on the growth of $F$. oxysporum $\mathrm{f}$. sp. gladioli

\section{Trichoderma isolate}

Trichoderma harzianum GJ16B isolate (NBAIR)

Trichoderma harzianum TN2A isolate (NBAIR)

Trichoderma harzianum HAR 4B isolate (NBAIR)

Trichoderma harzianum IIHR 9 isolate (native isolate)

Control

SEm \pm

CD at $1 \%$

Values following same letter don't differ significantly at $(\mathrm{P}=0.01)$

\section{Radial growth of $F$. oxysporum f. sp. Gladioli}

\begin{tabular}{|c|c|c|c|c|c|}
\hline \multicolumn{7}{|c|}{ Radial growth of $\boldsymbol{F}$. oxysporum f. sp. Gladioli } \\
\hline Growth $(\mathbf{c m})$ & $\begin{array}{c}\text { \% reduction } \\
\text { over control }\end{array}$ & $\begin{array}{c}\text { Growth } \\
(\mathbf{c m})\end{array}$ & $\begin{array}{c}\mathbf{5}^{\text {th }} \text { day } \\
\text { \% reduction } \\
\text { over control }\end{array}$ & $\begin{array}{c}\text { Growth } \\
(\mathbf{c m})\end{array}$ & $\begin{array}{c}\mathbf{7}^{\text {th }} \text { day reduction } \\
\text { over control }\end{array}$ \\
\hline $1.10^{\mathrm{d}}$ & 40.21 & $2.25^{\mathrm{d}}$ & 36.61 & $2.95^{\mathrm{c}}$ & 52.80 \\
\hline $1.3^{\mathrm{bc}}$ & 29.34 & $2.80^{\mathrm{b}}$ & 21.12 & $3.25^{\mathrm{b}}$ & 48.00 \\
\hline $1.15^{\mathrm{cd}}$ & 37.5 & $2.5^{\mathrm{c}}$ & 29.57 & $2.8^{\mathrm{c}}$ & 55.20 \\
\hline $1.4^{\mathrm{b}}$ & 23.91 & $2.65^{\mathrm{bc}}$ & 25.35 & $3.3^{\mathrm{b}}$ & 47.20 \\
\hline $1.84^{\mathrm{a}}$ & - & $3.55^{\mathrm{a}}$ & - & $6.25^{\mathrm{a}}$ & \\
\hline $\mathbf{0 . 0 6}$ & & $\mathbf{0 . 0 8}$ & & $\mathbf{0 . 0 5}$ & \\
\hline $\mathbf{0 . 2 1}$ & & $\mathbf{0 . 3 4}$ & & $\mathbf{0 . 2 6}$ & \\
\hline
\end{tabular}


Table.6 Effect of non-volatile compounds produced by selected isolates of Trichoderma on growth of $F$. oxysporum f. sp. gladioli

\begin{tabular}{|lr|c|c|}
\hline \multicolumn{2}{|c|}{ Trichoderma isolates } & $\begin{array}{c}\text { Dry mycelial weight of FOG (g/100 } \\
\text { ml) }\end{array}$ & $\begin{array}{c}\text { Per cent reduction over } \\
\text { control }\end{array}$ \\
\hline $\begin{array}{l}\text { Trichoderma harzianum } \\
\text { isolate (NBAIR) }\end{array}$ & GJ16B & 0.4790 & 56.29 \\
\hline $\begin{array}{l}\text { Trichoderma harzianum } \\
\text { isolate (NBAIR) }\end{array}$ & TN2A & 0.6870 & 37.31 \\
\hline $\begin{array}{l}\text { Trichoderma harzianum } \\
\text { isolate (NBAIR) }\end{array}$ & HAR4B & 0.7220 & 34.12 \\
\hline $\begin{array}{l}\text { Trichoderma harzianum } \\
\text { isolate (native isolate) }\end{array}$ & IIHR9 & 0.5744 & 47.59 \\
\hline $\begin{array}{l}\text { Control } \\
\text { SD }\end{array}$ & 1.096 & - \\
\hline
\end{tabular}

Studies on mycoparasitism of selected isolates of Trichoderma on $F$. oxysporum $f$. sp. dianthi and $F$. oxysporum f. sp. gladioli

The control of Fusarium wilt by Trichoderma isolates might be attributed to the pronounced colonization of rhizosphere by Trichoderma spp. in advance of the pathogen and also by mycoparasitism (Papavizas and Lewis, 1989). Similarly in the present investigation a strong coiling of FOG isolate by Trichoderma isolate GJ16B was observed. Trichoderma penetrated into Fusarium mycelium with its mycoparasitic ability and no coiling was observed by other Trichoderma isolates around FOG mycelium. The mycelia interaction and coiling between FOG mycelium and GJ16B was shown in plate 1 .

\section{References}

Bose, T.K., Yadav, L.P., Pat, Parthasarathy, V.A. and Das, P., 2003, Commercial flowers, Naya Udyog Kolkata, India, vol 2 .

Chandel, S. and Deepika, R. 2010, Recent advances in management and control of Fuarium yellows in gladiolus species. J. Fruit Orna. Pl. Res., 18(2): 361-380.
Cugudda, I. and Garibaldi, A., 1987, Soil suppressive to Fusarium wilt of carnation: studies on mechanism of suppressiveness. Acta Hort., 216:6776.

Dennis, C. and Webster, J., 1971a, Antagonistic properties of species groups of Trichoderma III, hyphae interaction. Trans. British. Mycol. Soc., 57:363-369.

Dennis, C. and Webster, J., 1971b, Antagonistic properties of species groups of Trichoderma II, Production of volatile antibiotics. Trans. British. Mycol. Soc., 57: 41-48.

Elad, Y. and Chet, I., 1983, Improved selective media for isolation of Trichoderma and Fusarium spp. Phytoparasitica, 11: 55-58.

El-Katatny, M.H., Gudelj, M., Robra, K.H., Elnaghy, M.A. AND Gubitz, G.M., 2001, Characterization of a chitinase and an endo-b-1,3-glucanase from Trichoderma harzianum, Rifai T24 involved in control of the phytopathogen Sclerotium rolfsii. Appl. Microbiol. Biotechnol., 56:137143.

Kamala, T.H. and Indra, S., 2011, Evaluation of indigenous Trichoderma isolates 
from Manipur as biocontrol agent against Pythium aphanidermatum on common beans. Biotech., 1: 217-225.

Marois, J.J. and Locke, J.C., 1985, Population dynamics of Trichoderma viride in steamed plant growth medium. Phytopathol., 75: 115-118.

Mishra, P.K., Mukhopadhyay, A.N. and Fox, R.T.V., 2004, Integrated and biological control of gladiolus corm rot and wilt caused by Fusarium oxysporum f. sp. gladioli. Ann. Appl. Biol., 137: 361-364.

Mukherjee, S. and Tripathi, H.S., 2000, Biological and chemical control of wilt complex of French bean. $J$. Mycol. Pl. Pathol., 30: 380-385.

Papavizas, G.C. and Lewis, J.A., 1989, Effect of Gliocaldium and Trichoderma on damping off and blight of snapbean caused by Sclerotium rolfsii the green house. Pl. Pathol., 38: 277.

Prayal, W.S., 1909, Diseases of gladioli, Rural new Yorker, 68:10009.

Riaz, T., Khan, S.N., Javail, N. 2008. Antifungal activity of plant extracts against Fusarium oxysporum. The cause of corm rot disease of gladiolus. Mycopathology 6: 13-15.

Sivan, A., Ucko, O. and Chet, I. 1987, Biological control of Fusarium rot of tomato by Trichoderma harzianum under field conditions. Pl. Dis., 71:587-592.

Sivan, A. and Harman, G.E., 1991, Improved rhizosphere competence in a protoplast fusion progeny of Trichoderma harzianum. J. Can. Microbol., 137: 23-30.

Singh, R.N., 1969, A vascular disease of gladiolus caused by Fusarium oxysporum f.sp. gladioli in India. Indian Phytopathol., 22: 402-403.

Tomar, M., 1997, Studies on the management of gladiolus yellows caused by Fusarium species. M.Sc. thesis, Dr. Y. S. Parmar University of Horticulture and Forestry, Solan.

Vicent, J.M., 1927, Distortion of fungal hyphae in the presence of certain inhibitors. Nature, 159: 850.

Watanabe, N., 1984, Antagonism by various kinds of Trichoderma fungi to soil born plant pathogen. Bulletin of Faculty of Agriculture, Maiji University, Japan.

Widden, P. and Scattolin, V., 1988, Competitive interactions and ecological strategies of Trichoderma species colonizing spruce litter. Mycologia., 80: 795-803.

\section{How to cite this article:}

Venkatesh Javali, S. Sriram and Neethu K. Chandran. 2019. Evaluation of Biocontrol Agents in Management of Wilt Disease of Gladiolus Caused by Fusarium oxysporum F. Sp. Gladioli. Int.J.Curr.Microbiol.App.Sci. 8(06): 756-765. doi: https://doi.org/10.20546/ijcmas.2019.806.090 